\section{CARDIAC OUTPUT MONITORING IN CHILDREN BY BIOREACTANCE; A NEW METHOD FOR NONINVASIVE CARDIAC OUTPUT MEASUREMENT}

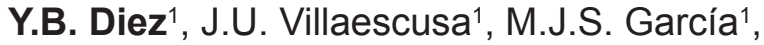 \\ M.B. Prieto ${ }^{1}$, J.L.-H. Cid ${ }^{1}$, A. Laborda ${ }^{2}$ \\ ${ }^{1}$ Pedriatic Intensive Care, ${ }^{2}$ Preventive and Quality \\ Control Service, Hospital General Universitario \\ Gregorio Marañón, Madrid, Spain
}

Introduction: Bioreactance, the analysis of intrabeat variations in response to high frequency transthoracic current, is a new method for noninvasive cardiac output measurement (NICOM). The objective of this study was to evaluate the cardiac index $(\mathrm{Cl})$ by bioreactance in children without hemodynamic alterations.

Methods: We performed a prospective, observational study in 10 patients with age range between 1 month to 12 years and weight from 4 to $30 \mathrm{Kg}$. The heart rate (HR), mean arterial pressure (MAP) and $\mathrm{Cl}$ by bioreactance were analyzed every 6-8 hours.

Results: 34 measurements were made. The mean $\mathrm{Cl}$ was $2.4 \pm 1.03 \mathrm{ml} / \mathrm{min} / 1.73 \mathrm{~m}^{2}$ (range 1 to $4.9 \mathrm{ml} /$ $\left.\mathrm{min} / 1.73 \mathrm{~m}^{2}\right) .52 \%$ of the measurements were lower than $2.5 \mathrm{~L} / \mathrm{min} / 1.73 \mathrm{~m} 2$. A significant correlation was found between $\mathrm{Cl}$ and age $(r=0.50, p=0.003)$, weight $(r=0.66, p<0.001)$ and MAP $(r=0.369, p$ $=0.037$ ). Significant differences were found when comparing $\mathrm{Cl}$ in children whose weight was $<10$ $\mathrm{kg}$ : $1.9 \pm 0.73 \mathrm{ml} / \mathrm{min} / 1.73 \mathrm{~m}^{2}$ (range 1 to $3.2 \mathrm{ml} /$ $\left.\mathrm{min} / 1.73 \mathrm{~m}^{2}\right), 10$ and $20 \mathrm{~kg}: 2.07 \pm 0.7 \mathrm{ml} / \mathrm{min} / 1.73$ $\mathrm{m}^{2}$ (range 1 to $3.6 \mathrm{ml} / \mathrm{min} / 1.73 \mathrm{~m}^{2}$ ) and $>20 \mathrm{~kg}: 3.7$ $\pm 0.8 \mathrm{ml} / \mathrm{min} / 1.73 \mathrm{~m}^{2}$ (range 2.4 to $4.9 \mathrm{ml} / \mathrm{min} / 1.73$ $\left.m^{2}\right)(p<0.001)$.

Conclusion: In children $\mathrm{Cl}$ values by bioreactance change with patient's age and weight. In a large percentage of measurements these might be lower than normal range. These data suggests that this method may not be useful to measure $\mathrm{Cl}$ in small children.

\section{N-TERMINAL PRO-BRAIN NATRIURETIC PEPTIDE LEVELS AND ITS RELATION WITH THE PATENT DUCTUS ARTERIOSUS IN PREMATURE NEONATES}

\author{
S. Yildirim ${ }^{1}$, A. Gumus ${ }^{2}$, H. Gulcan ${ }^{3}$
}

${ }^{1}$ Pediatric Cardiology, Baskent University, ${ }^{2}$ Pediatric Cardiology, ${ }^{3}$ Neonatalogy, Baskent University, Adana Teaching and Medical Research Center, Adana, Turkey

Introduction: Early and definitive detection of PDA is possible with echocardiography, but it is not practical for screening all the premature babies. The purpose of this study is evaluating the relationship with the NT- proBNP and PDA in premature babies.

Patients and method: 43 prematures, gestational ages between 27-36 weeks, >750 g, within the first 48 hours enrolled the study. Echocardiography perrformed with/without clinical signs of PDA and first blood samples for pro-BNP (proBNP 0) were obtained. Echocardiography repeated at $5^{\text {th }}, 15^{\text {th }}$ and $30^{\text {th }}$ days if it had been determined open duct. The second blood samples for pro-BNP (proBNP 5) were obtained at $5^{\text {th }}$ day. Mean ages of prematures were $28.8 \pm 10.0$ hours, gestational ages were 31.3 \pm 2.3 weeks, mean weights were $1531.2 \pm 389.1$ gram. We found open duct in $19(44.2 \%)$ babies during first echo, in $9(20.9 \%)$ babies on $5^{\text {th }}$ day echo. On the $15^{\text {th }}$ day, 5 ducts were patent. On $30^{\text {th }}$ day, 3 ducts were open.

Results: Mean proBNP 0 were significantly different between open duct $(13893.8 \pm 12048.1 \mathrm{pg} / \mathrm{mL})$ vs closed duct $(6132 \pm 3913.8 \mathrm{pg} / \mathrm{mL})(\mathrm{P}<0.005)$. We found that mean proBNP 5 level was significantly different in open duct babies vs closed duct babies $(8407.4 \pm 11029.9 \mathrm{pg} / \mathrm{mL}$ vs. $1789.2 \pm 1724.4 \mathrm{pg} /$ $\mathrm{mL}, \mathrm{P}<0.005)$. There was negative correlation between proBNP 0 levels and gestational age $(r=$ $-0.32)$, proBNP 0 levels and weight $(r=-0.31)$

Conclusion: The proBNP predictivity of the outcome in PDA in prematures is insufficient. 